\title{
UKRAINE - TYPE OF ARMED CONFLICT
}

\author{
Sabin GUȚAN \\ “Nicolae Bălcescu" Land Forces Academy, Sibiu, Romania \\ sabin_gutan@yahoo.com
}

\begin{abstract}
The armed conflict in Ukraine raises questions about the typology of armed conflicts and the application of international humanitarian law in modern armed conflicts. Many controversies are found at international level regarding the involvement of other countries in the armed conflict in Ukraine. In this study we intend to analyse facts and international norms regarding the armed conflict in Ukraine and establish the kind of conflict and therefore what the applicable rules of international law are.
\end{abstract}

\section{Keywords: armed conflict, Ukraine, international humanitarian law}

\section{Introduction}

Currently, no one can deny the existence of an armed conflict in Ukraine. The big question is: what type of armed conflict can one encounter in this country? The answer, though simple at first sight, becomes more difficult when we analyse the armed conflict more closely.

Given the complexity of international relations and of the public international law, such a conflict cannot be analysed from the legal point of view, just by itself, but we should appeal to a number of factors outside the conflict, including those of a historical nature. Such a historical factor is the "imperialism" as the cause of many current conflicts and tensions. We must not forget that the space of the former empires was the nursery of many modern conflicts. Besides the desire of peoples to free themselves from the yoke of imperialism, in order to rebuild their own countries, there appears the tendency of the populations colonized in the territories conquered and annexed by the former empires to retain the rights acquired in these territories. This is the case of Ukraine, a state encompassing territories that previously belonged to other states, territories where there live today, in addition to ethnic Ukrainians, a number of other ethnic groups, some of which represent the majority in some areas. The most important ethnic group in Ukraine, after the Ukrainians, is that of the Russians.

Actually, the armed conflict areas in Ukraine overlap with the areas where Russians represent a big percentage of the population. This is the very essence of the political conflict: the Russians want to separate from the rest of Ukraine and to annex these territories to Russia (which has already happened in Crimea) - so the rebels are often called "pro-Russians".

In the context of armed confrontations within Ukraine, there appears the internationalization of the crisis through the geostrategic interests of the main actors from the international sphere: NATO and the EU, on the one hand, and the Russian Federation, on the other hand. The frenzy of mutual accusations from both 
sides regarding the direct involvement in the conduct of hostilities makes the legal classification of the type of armed conflict difficult.

It can be said that it is not important to establish the type of armed conflict, because there are enough international factors to ensure the conduct of this conflict within the limits of the international humanitarian law. However, international humanitarian law is applied differently, depending on the type of armed conflict.

1.1. The types of armed conflict under international humanitarian law

Analysing the provisions of international treaties is of particular importance for determining the type of armed conflict in Ukraine. The most important international treaties in this area are the four Geneva Conventions of 1949 and their Additional Protocols of 1977. It should be noted that the treaties before 1949 refer only to conflicts between states, i.e. international ones. Only in 1949, by Article 3 common to the four Geneva Conventions, the armed conflict that is not of an international (or internal) character is recognized. The documents mentioned above refer to two types of armed conflict: international and internal. In the practice of states and in the international doctrine, specialists have identified other types of conflicts, but these are based on the two aforementioned types (internationalized internal armed conflict, extraterritorial internal armed conflict, deconstructed armed conflict). The armed conflict is not defined in these treaties, they just establish the situations where international humanitarian law is applied.

The international armed conflict has as a legal basis Article 2 common to the Geneva Conventions of 1949 and is developed by Article 1, para. 4 of Additional Protocol I of 1977. Thus, the common Article 2 reads:

„In addition to the provisions which shall be implemented in peacetime, the present Convention shall apply to all cases of declared war or of any other armed conflict which may arise between two or more of the High Contracting Parties, even if the state of war is not recognized by one of them.

The Convention shall also apply to all cases of partial or total occupation of the territory of a High Contracting Party, even if the said occupation meets with no armed resistance. $[\ldots]$ "..

The essence of this provision is that an international armed conflict between states is waged only under given conditions, only the signing states are compelled to respect these conventions, the rest of the states abiding, however, by the customary international humanitarian law.

Article 1, para. 4, of Additional Protocol I of 1977 develops the sphere of international armed conflict thus: "The situations referred to in the preceding paragraph include armed conflicts in which peoples are fighting against colonial domination and alien occupation and against racist regimes in the exercise of their right of self-determination, as enshrined in the Charter of the United Nations and the Declaration on Principles of International Law concerning Friendly Relations and Co-operation among States in accordance with the Charter of the United Nations." This paragraph is of particular importance, given that certain organized armed groups receive, according to the international humanitarian law, the same legal status that the states receive through the common Art 2, in the context of the rights of peoples to dispose of themselves.

The internal armed conflict was first regulated, briefly, in Article 3 common to the Geneva Conventions of 1949, as follows: "In the case of armed conflict not of an international character occurring in the territory of one of the High Contracting Parties, each Party to the conflict shall be bound to apply, as a minimum, the following provisions [...]". This article shows that an internal armed conflict may 
take place between government forces and non-governmental armed groups or only between such groups.

The internal armed conflict is covered in more detail in Article 1 of Additional Protocol II of 1977, as follows: "This Protocol, which develops and supplements Article 3 common to the Geneva Conventions of 12 August 1949 without modifying its existing conditions of applications, shall apply to all armed conflicts which are not covered by Article 1 of the Protocol Additional to the Geneva Conventions of 12 August 1949, and relating to the Protection of Victims of International Armed Conflicts (Protocol I) and which take place in the territory of a High Contracting Party between its armed forces and dissident armed forces or other organized armed groups which, under responsible command, exercise such control over a part of its territory as to enable them to carry out sustained and concerted military operations and to implement this Protocol." Although this regulation develops and supplements the common Article 3 , it makes it in a restrictive manner, reducing the application of Additional Protocol II only to the internal armed conflicts between government forces and organized armed groups (under the condition of effective control of a territory), the other internal armed conflicts remaining under the application of the common Article 3. [1]

\subsection{The role of jurisprudence in defining and establishing the type of armed conflict}

As we can see, these regulations are not sufficient to determine the type of armed conflict, especially for situations that do not meet the "classic" criteria. Modern conflicts have often raised questions about the application and timeliness of international humanitarian law. To eliminate these shortcomings, some international criminal tribunals and the International Court of Justice had to define and specify certain parameters for determining the type of armed conflict. This approach is not easy, sparking controversy and contradictions between different Courts. A very important thing to be said about the jurisprudence of these tribunals: their decisions regard certain armed conflicts and even if some elements are well known and widely accepted (such as the definition of the armed conflict), they are not sources of law and may not be applied to all armed conflicts as such, because a decision of an international court cannot change the content and the letter of an international treaty. [2]

The armed conflict - international and internal - is defined, generally, by the Court of Appeals of the International Tribunal for the former Yugoslavia, in the case of Tadic, as follows: "[...] an armed conflict exists whenever there is a resort to armed force between States or protracted armed violence between governmental authorities and organized armed groups or between such groups within a State. International humanitarian law applies from the initiation of such armed conflicts and extends beyond the cessation of hostilities until a general conclusion of peace is reached; or, in the case of internal conflicts, a peaceful settlement is achieved. Until that moment, international humanitarian law continues to apply in the whole territory of the warring States or, in the case of internal conflicts, the whole territory under the control of a party, whether or not actual combat takes place there."[3]

Special issues on the enforcement of international humanitarian law occur when the type of armed conflict deviates from the classic classification described above. In some situations, internal armed conflicts exceed the territory of a single state, the insurgents acting withing/from the territory of other states (generally neighbouring countries of the state where the conflict occurs). In this case, government forces have to carry out hostile actions against insurgents entering the territory of these states. In the case of the conflict in 
Afghanistan, for example, we find such a situation. This was originally an international conflict between the US-led coalition - "Operation Enduring Freedom" and Afghanistan, ruled by the Talibans, between October 7, 2001 and June 18, 2002. After this date, with the establishment of a government recognized by the international community, armed conflict became internal between the Afghan Government, supported by the international coalitions (ISAF and OEF), and the armed groups of Talibans and Al Qaeda. For the internal armed conflict Article 3 common to the Geneva Conventions of 1949 was applied until 10 November 2009, when the Afghan state ratified Additional Protocol II, which has thus become applicable. [4] This conflict has extended to other states, without their direct involvement, especially the US pursuing and attacking opponent fighters in these territories. This conflict is called extraterritorial and can become international when the state, in whose territory they fight, opposes (Israel's attack against the positions of Hezbollah on Lebanese territory, in 2006) or may remain internal when there is the consent (even a tacit one) of the state in whose territory they act. [5]

Other types of armed conflict, initially internal, can become international through the intervention of a foreign state or coalition of states in favour of nongovernmental forces. In recent years we find, at international level, a number of examples: NATO's intervention in the former Yugoslavia (1999), the intervention of the international coalition in Libya (2011), the US support for rebels in Nicaragua in the 80s. This type of conflict is quite difficult to classify, especially when the intervening State does not recognize its involvement. Therefore, it was necessary to involve international courts to establish criteria for determining such a type of armed conflict. In this regard, international jurisprudence has offered several tests for the classification of an armed conflict as an internationalized armed conflict. [6] Thus, in the case Nicaragua v. the United States, the International Court of Justice proposed the test of "effective control" which involved determining the situation that "the relationship of the contras to the United States Government was so much one of dependence on the one side and control on the other that it would be right to equate the contras, for legal purposes, with an organ of the United States Government, or as acting on behalf of that Government." [7] In the Tadic case, the Appeals Chamber of the International Criminal Tribunal for the former Yugoslavia established that: 'It is indisputable that an armed conflict is international if it takes place between two or more States. In addition, in case of an internal armed conflict breaking out on the territory of a State, it may become international (or, depending upon the circumstances, be international in character alongside an internal armed conflict) if (i) another State intervenes in that conflict through its troops, or alternatively if (ii) some of the participants in the internal armed conflict act on behalf of that other State.’[8]

The Appeals Chamber of the International Criminal Tribunal for the former Yugoslavia, analysing the restrictive conditions adopted by the International Court of Justice, accepted the evidence of effective control of a third State on the insurgents, beyond funding and equipping these forces by planning, organizing and coordinating military operations, which is sufficient to consider the armed conflict as an international one. [9]

\section{The type of armed conflict in Ukraine}

The armed conflict in Ukraine is recognized internationally, but there is no official identification of the type of armed conflict. Moreover, the international community is working hard to conclude a ceasefire between the parties involved in the conflict and to restore peace. The deepest controversies were related to the 
kind of conflict and to the applicable law. The core of this controversy is the involvement of Russia in this conflict and the support it gives to the insurgents. Similarly, the annexation of Crimea by Russia has generated extensive debate and controversy about the compliance with and the enforcement of the international law.

\subsection{The evolution of the Ukrainian conflict}

The political crisis in Ukraine began with internal disturbances and tensions because the authorities had given up the process of Ukraine's integration into NATO and the EU structures. In early 2014, protests led to the fleeing of the Ukrainian president to Russia. Subsequently, the violence spread to several regions of Ukraine, the opposing parties being the proEU militants and the pro-Russian militants.

Since March 2014, the pro-Russian groups armed themselves and began to occupy the headquarters of the local authorities in Donetsk, Luhansk and other places in eastern Ukraine, proclaiming the "Donetsk People's Republic" and the "Luhansk People's Republic". The government ordered armed operations against the insurgents in mid-April, calling them "anti-terrorist operations." Since then armed confrontations have generated legal and political controversy. What is certain is the fact that the civilian population has suffered greatly, with many casualties and destruction.

The Crimean situation is slightly different, this province with a majority Russian of population, benefiting from autonomy. In February 2014, protests began in the Crimea region and in March, the Parliament voted for joining Russia; the vote was confirmed through a controversial referendum. These actions were supported by a large and very well prepared military component. Russia has been accused by the international community that sent troops and weapons in Crimea, but Russian authorities deny any involvement, claiming that there are local self-defence forces and the Russian citizens who are fighting along with the rebels are volunteers. [10] However, the Russian Federation annexed Crimea and sent troops to take control, forcing Ukrainian troops to retreat or surrender. Although Crimea is an autonomous province, it is under the sovereignty of Ukraine. The actions of force conducted for independence and for joining the Russian Federation violate the Ukrainian constitution and a number of international agreements regarding the integrity and sovereignty of Ukraine.

In Crimea there have been few and sporadic clashes, although the Ukrainian and the Russian military presence (a Russian military base established with the consent of the Ukrainian authorities) was massive. In this context, the Crimean independence and its inclusion in the Russian Federation is a political act, rather than a military one.

\subsection{Actors involved in the Ukrainian armed conflict}

Ukraine, as a sovereign state, is the main actor. On the other hand, we find the insurgent forces acting in Donetsk, Luhansk and other areas of eastern Ukraine in order to break these territories from Ukraine. These insurgent forces are armed, organized, having a hierarchical structure and control over certain territories.

Another actor, whose involvement is evident in Crimea is Russia. Although in Crimea a number of soldiers in uniforms without any identification marks exist, their association with Russia is difficult to make without an international investigation carried out judiciously. Furthermore, considering the Autonomous Republic of Crimea as a special actor raises a number of questions. The political actions that occurred within this autonomous republic are overshadowed by the lack of a process of democratic proclamation of independence and by controversies regarding the legality of the organization and the conduct of the referendum. 


\subsection{The type of conflict and the applicable law}

If the involvement of the Ukrainian government forces and of the so called proRussian rebel forces in the conflict is obvious, Russia's involvement in the armed conflict is controversial and uncertain. Under these circumstances, determining the type of the armed conflict can be done, under international humanitarian law, just for clear and obvious elements, following that when a legitimate court will judge violations of international humanitarian law in this conflict, it will identify all the actors involved and will establish the kind of conflict in this context. Until then, for the unclear situations we cannot analyse the type of conflict, unless by formulating hypotheses.

In terms of international humanitarian law, Ukraine has ratified both the Geneva Conventions of 1949 and their Additional Protocols of 1977. Accordingly, they are applicable all over Ukraine.

The first and most obvious element in the analysis of the type of armed conflict in Ukraine is the confrontation between the government forces and the organized nonstate armed groups in different regions of the state. Apparently, we are in the presence of a non-international armed conflict, as regulated in Article 3 common to the four Geneva Conventions of 1949 and Article 1 of Additional Protocol II of 1977. If the application of the common Article 3 is not questionable in any internal armed conflict, being applied even in the so-called deconstructed armed conflicts, the application of Additional Protocol II of 1977 is subject to a number of limiting factors covered by Article 1 of this Protocol. The first condition imposed by this article is the waging of hostilities between government forces and dissident armed groups, which excludes its application to internal armed conflicts between non-state armed groups. The second limiting condition is that the nonstate armed group be placed under a responsible command, which entails the presence of a leader or a hierarchy able to subordinate and control the activity of group members, and, of course, to assume the legality of the actions of the group and of its members. The third condition for the application of this protocol is that the organized non-state armed group should exercise such control over a part of its territory so as to enable them to carry out sustained and coordinated military operations. The Protocol does not impose any criteria on the size of the occupied territory. Under these circumstances, military action conducted in this territory should be continuous and planned. [11] The last condition found in Article 1 of Additional Protocol II is that these organized dissident armed groups be organized in such a manner and control a territory that would enable them to apply this protocol.

Whether or not the conditions are met for the application of Additional Protocol II, the common Article 3 applies throughout the entire duration of the internal armed conflict. At this level of analysis, we consider that in Ukraine there is an internal armed conflict to which, at first, the common Article 3 was applied and later Additional Protocol II became applicable, because the conflict is carried between government forces and dissident armed groups. These armed groups have a responsible command that controls and manages vast territories, enabling them to conduct sustained and coordinated military operations and to apply the Protocol.

Given that an internal armed conflict, in terms of terminology, is found in treaties under the name of noninternational armed conflict, in order to declare it as such, one has to prove the impossibility of applying the provisions regarding the international armed conflict. The first situation is the armed conflict between at least two states, as required by Article 2 common to the four Geneva Conventions of 1949, which is not the case. 
Another situation is the application of Article 1, paragraph 4 of Additional Protocol I of 1977. This is about a war of national liberation. We might be tempted to believe that the pro-Russian population raised to fight against Ukraine could claim such a right, especially since the rebel leaders have often declared their desire of separation from Ukraine and the unification with Russia. One could invoke in support of this idea, the historical context of these provinces. These territories belonged to Russia more than fighting they belonged to Ukraine and have a large ethnic Russian population. However, a prerequisite for the application of Article 1, paragraph 4, of Additional Protocol I of 1977 is found in Article 96, paragraph 3, of this Protocol, namely:

"The authority representing a people engaged against a High Contracting Party in an armed conflict of the type referred to in Article 1, paragraph 4, may undertake to apply the Conventions and this Protocol in relation to that conflict by means of a unilateral declaration addressed to the depositary. Such declaration shall, upon its receipt by the depositary, have in relation to that conflict the following effects:

a) the Conventions and this Protocol are brought into force for the said authority as a Party to the conflict with immediate effect;

b) the said authority assumes the same rights and obligations as those which have been assumed by a High Contracting Party to the Conventions and this Protocol; and

c) the Conventions and this Protocol are equally binding upon all Parties to the conflict."

This statement has not been made, therefore conflict remains under the power of common Article 3 and Additional Protocol II.

As far as the internationalization of the armed conflict is concerned, the international humanitarian law treaties do not provide measurement instruments, the only instruments that can be found are those in the jurisprudence of international courts (the International Criminal Tribunal for the Former Yugoslavia, the International Court of Justice). However, the application of a particular solution (the internationalization of the armed conflict in Bosnia or the internationalization of the armed conflict in Nicaragua) to other armed conflicts, with other actors, other causes and a different context is questionable. The two courts mentioned above have not reached a consensus, contradicting each other. Under these circumstances, the internationalization of the armed conflict in Ukraine will be confirmed either by direct involvement of other states in the conflict, or by a special court.

\section{Conclusions}

All these measuring instruments at jurisprudential level do not clarify the issue of determining the type of armed conflict and the correct application of the international humanitarian law. Moreover, the international humanitarian law accumulates more lacunae from one armed conflict to another. The present proves that the dilemmas and controversies regarding the existence or the type of armed conflict lead to major difficulties in achieving the purpose of the international humanitarian law, namely the protection of the people, of the society and of the environment against war.

The armed conflict in Ukraine, although it inflamed the international politics more than the terrible slaughter carried out by the so-called "Islamic State" still has not found its precise place in international humanitarian law. Actually, it is an internal armed conflict. The international, political, geo-strategic, historic context complicates things and can generate the internationalization of the conflict.

What comes out from the difficulty and the controversy regarding the determination of the type of armed conflict 
- not only in Ukraine - is an urgent need for states to remodel certain provisions of the international humanitarian law so that it can be applied immediately and completely, without interference in this artificially created problem: the type of armed conflict. Both states and non-state armed groups should be compelled to assume compliance with the international humanitarian law without classification of the type of conflict, thus, protection would be more effective and nobody could flee from certain obligations enshrined in international treaties.

\section{References}

[1] ICRC, How is the Term 'Armed Conflict' Defined in International Humanitarian Law? ICRC Opinion Paper, March 2008, https://www.icrc.org/eng/assets/files/other/opinionpaper-armed-conflict.pdf

[2] Sten Verhoeven, International and Non-international Armed Conflicts, Working Paper No. 107, March 2007, 10at www.internationallaw.be,

[3] ICTY, The Prosecutor v. Dusko Tadic, Decision on the Defence Motion for Interlocutory Appeal on Jurisdiction, IT-94-1-A, 2 October 1995, para. 70.

[4] R. Geiß and M. Siegrist - Has the armed conflict in Afghanistan affected the rules on the conduct of hostilities?, International Review of the Red Cross, Volume 93, Number 881, March 2011, 13-16

[5] Marco Sassòli, Transnational Armed Groups and International Humanitarian Law, Program on Humanitarian Policy and Conflict Research, Harvard University, Occasional Paper Series, Winter 2006, Number 6, 3-5

[6] Beatrice Onica-Jarka, Drept internaţional umanitar. Note de curs, Editura Universul Juridic, București, 2011, 21-22

[7] ICJ, Case concerning military and paramilitary activities in and against Nicaragua (Nicaragua v. United States of America), Judgment of 27 June 1986, para.109, http://www.icj-cij.org/docket/files/70/6503.pdf

[8] Prosecutor vs. Dutko Tadic, Tribunalul Penal International pentru fosta Iugoslavie, Camera de Apeluri, Caz nr. IT-94-1-A, para.84, http://www.icty.org/x/cases/tadic/acjug/en/tad-aj990715e.pdf

[9] Dieter Fleck (ed.), The Handbook of International Humanitarian Law, Second Edition, Oxford: Oxford University Press, 2010, 606

[10] Digvijay Rewatker, Rithika Vidyut Shenoy, Crimea: A Tug of War Between Ukraine and Russia, International Journal of International Law, Volume 1, Issue 1, Published By: Universal Multidisciplinary Research Institute Pvt Ltd, 8-10

[11] Sten Verhoeven, International and Non-international Armed Conflicts, Working Paper No. 107, March 2007, 11 at www.internationallaw.be, 